Мила Ђуричић ${ }^{1}$

Висока бродарска школа Београд
Удк811.161.1'243(497.11)

371.1::811.161.1(497.11)

DOI https://doi.org/10.18485/zivjez.2017.37.1.12

Оригинални научни рад

\title{
ПОСТИГНУЋА У РАЗУМЕВАњУ ПИСАНОГ ТЕКСТ НА РУСКОМ ЈЕЗИКУ ПОСЛЕ ОПШТЕГ СРЕДЊЕГ ОБРАЗОВАЊА ${ }^{2}$
}

Циљ овог рада јесте испитивање стандарда постигнућа ученика после завршеног општег средњег образовања у области читања са разумевањем непознатог текста на руском језику. Узимајући у обзир излазне нивое стандарда постигнућа које предвиђа Заједнички европски оквир за живе језике, представљене скалом усвајања језичких вештина од А1 до Ц2, интересовало нас је да ли ученици гимназија и у ком проценту након завршеног општег средњег образовања достижу напредни ниво, који одговара нивоу Б2. Читање је од свих језичких вештина најзаступљеније у настави руског језика у српским школама. Сматрали смо да је добро развијено и због тога смо хтели да истражимо управо постигнућа из ове језичке вештине. Желели смо да проверимо колики проценат ученика достиже напредни ниво, прописан стандардима постигнућа (једнак нивоу Б2 према Заједничком европском оквиру за живе језике). Резултати истраживања су потврдили наше претпоставке: проценат испитаника који је достигао напредни ниво био је 50\%.

Кључне речи: читање, језичке вештине, стандарди, постигнућа, други страни језик, Прва београдска гимназија, настава читања на руском језику, тестирање, истраживање.

\section{Увод}

Пракса, искуство и ставови методичара о учењу генетски сродних језика показали су да српски ученички аудиторијум

1 puskinistkinja@gmail.com

2 Рад представља истраживачки део мастер рада Настава читања и постигнућа ученика у читању на руском језику после завршеног општег средњег образовања одбрањеног у септембру 2017. године на Филолошком факултету Универзитета у Београду. 
Мила Ђуричић

од четири језичке вештине - слушање, писање, говорење и читање - најбоље савладава последњу. С обзиром на то да руски и српски језик припадају групи словенских језика, природно је да српски говорник уз основна знања фонетике, морфологије и творбе речи може да разуме или наслути значење више од 50\% речи руског језика (Гинић 2016: 187-188). Захваљујући тој чињеници, при читању на руском језику више је заступљено беспреводно читање или читање без коришћења речника, него при читању на другом страном језику који није сродан српском (Тешић 1982: 157-158). Српски говорник може да разуме руски текст и када је недовољно добро савладао технике читања. Тада говоримо о кулминацији у читању која се достиже разумевањем информације. Истраживали смо да ли ученици београдских гимназија нефилолошких профила, који уче руски језик као други страни језик, након четворогодишњег образовања достижу претпостављене нивое у задовољавајућем броју и оправдавају нашу хипотезу о добром савладавању дате језичке вештине.

\section{Стандарди постигнућа и нивои}

Нивое и захтеве у свакој говорној делатности формулисао је Завод за вредновање квалитета образовања и васпитања у документу Општи стандарди постигнућа за крај општег средњег и средњег стручног образовања у делу општеобразовних предмета за предмет страни језик усвојеном 2013. године. Њега су сачинили наставници, професори, педагози и психолози уз помоћ стручних лица из Завода за вредновање квалитета образовања и васпитања и Завода за унапређивање образовања и васпитања. У документу су дефинисали стандарде и нивое постигнућа за стране језике који се уче у школама у српској средини. Стандардима се описује и процењује шта ученици треба да савладају и усвоје на одређеном нивоу. Према стандардима се мери ниво остварене компетенције који је постигао ученик на крају образовања. 
ПОСТИГНУЋА У РАЗУМЕВАЬУ ПИСАНОГ ТЕКСТ НА РУСКОМ ЈЕЗИКУ...

Стандарде постигнућа и нивои у оквиру стандарда дефинисани су усвојеним документом. За сваку компетенцију дефинисана су три нивоа постигнућа - основни, средњи и напредни. Сваки ниво подразумева знање, вештине и ставове који ученици треба да поседују како би испунили тај стандард. Да би се одређени ниво задовољио, ученик треба да поседује одређена знања и вештине, прописане конкретним стандардом на конкретном нивоу. На основном нивоу ученик треба да поседује одређено знање и вештине како би могао активно да учествује у различитим областима живота (друштву, привреди, образовању, породици); на средњем нивоу треба да стекне та знања како би могао успешно да настави са факултетским образовањем у различитим областима, док би усавршавање у једној области, за коју је предуслов познавање одређених знања и вештина, наставио на напредном нивоу (у: Општи стандарди постигнућа за крај општег средњег и средњег стручног образовања у делу општеобразовних предмета за предмет страни језик 2015: 5-6).

За сваки ниво аутори су тестирањем дошли до резултата колики проценат ученика овладава одређеним компетенцијама (у: Општи стандарди постигнућа за крај општег средњег и средњег стручног образовања у делу општеобразовних предмета за предмет страни језик 2015: 40-41):

- Основни ниво - $80 \%(+/-20 \%)$ ученика

- Средњи ниво - 50\% ученика (+/- 20\%) - знањима су овладали сви просечни ученици

- Напредни ниво - $20 \%$ ученика (+/- $10 \%)^{3}$.

Најважније карактеристике текста за читање према Заједничком европском оквиру (2003) за језичке нивое које смо истраживали (А1-Б2) јесу следеће:

1) За нивое A1/A2 (истраживали смо оба, а основни ниво после завршеног средњег образовања поклапа се са A2 нивоом према Заједничком европском оквиру), основне карактеристике захтева су: кратки, једноставни текстови у којима има познате лексике. То могу бити и текстови-писма, као и инструкције, огласи.

3 У нашем истраживању ове вредности су се показале као прецизне. 
Мила Ђуричић

2) У нивоу Б1 и стандарду постигнућа за средњи ниво акценат се ставља на емоционално-психолошке односе/ догађаје, који су написани стандардним језиком. Кандидат разуме и пословну језичку терминологију.

3) Савладавши претходне нивое, на нивоу Б2 кандидат би требало да разуме савремена питања, посебна гледишта или лични став аутора. Са овим нивоом паралелни су стандарди постигнућа за напредни ниво, који претпостављају разумевање различитих ставова, стручних текстова и чланака, као и књижевне и популарне текстове.

\section{Опис истраживања и резултати}

Истраживање је обављено у априлу 2017. године у просторијама Прве београдске гимназије са ученицима завршне године, у две етапе. Првог дана ученици су решавали тестове нивоа A1 и A2, а другог дана тестове нивоа Б1 и Б2 на редовним часовима руског језика. За тестирање је било предвиђено 30 минута. У истраживању су учествовали ученици два одељења $-4 / 6$, 4/2 и 4/4 (последња два обједињена су у једно одељење, јер једна половина ученика похађа руски језик, а друга немачки). Укупно је учествовало 55 ученика. Бавили смо се испитивањем сва три нивоа (основног, средњег и напредног) стандарда постигнућа који прате нивое од А2+ до Б2 према Заједничком језичком оквиру за живе језике. У анализу смо укључили и ниво A1. Нису сви ученици учествовали у обе етапе тестирања: 38 ученика је урадило обе етапе, а њих 17 по једну. Тестове су решавали индивидуално, читањем у себи, беспреводним поступком (изузетак је направљен на напредном нивоу, на коме су ученици могли да питају за значење укупно три речи), неприпремљено, у мањој или већој мери студиозно. Будући да се при полагању ове језичке вештине може користити речник, сматрамо да нисмо иступили из оквира који су прописани за полагање ове језичке вештине. 
ПОСТИГНУЋА У РАЗУМЕВАњУ ПИСАНОГ ТЕКСТ НА РУСКОМ ЈЕЗИКУ...

Одлучили смо се да тестирање не буде анонимно. При анонимном тестирању, ученици нису мотивисани да дају свој максимум приликом израде. Ученицима је речено да ће онима који добро ураде тест резултати утицати на закључну оцену. Овим смо обезбедили максимум мотивације за саму израду теста и сматрамо валидним резултате које смо добили. Сумирајући резултате, увидели смо да се закључне оцене углавном подударају са нашим претпоставкама о достигнутом нивоу.

Предистраживачки рад је подразумевао проналазак текстова и састављање тестова за испитивање. Адаптирани текстови за сваки ниво су преузети са електронског извора Текстотека ЦМО (http://texts.cie.ru/). Текстови презентовани на датом сајту су текстови које су стручњаци за руски језик као страни Центра међународног образовања Московског државног универзитета „М. В. Ломоносов“ адаптирали за конкретан језички ниво (А1-Б2). Они не излазе из опсега лексичког, граматичког и синтаксичког минимума прописаног за сваки конкретан језички ниво. Критеријуми којима смо се водили при одабиру текстова били су: занимљивост, савременост, духовитост. Преузели смо четири текста: В один прекрасный день, Первая любовь, Мифы и правда о России и Мужской и женский русский. Шест посттекстуалних вежби је пратило сваки текст. Свако питање носило је по један поен. Питања су била затвореног типа (два питања алтернативног избора и два вишеструког избора) и отвореног типа (два питања).

Како смо се бавили само разумевањем текста, у нашим посттекстуалним вежбама није било места за задатке који се тичу других језичких вештина. Трудили смо се да питања буду таква да ученици избегну позитиван/негативан трансфер. Нисмо узимали у обзир језичке грешке у питањима отвореног типа које нису реметиле разумевање. Истраживање је показало да

4 На пример, ученик са закључном оценом 3 требало би да достигне ниво А2, са 4 А2/Б1, а са 5 - Б2, што се није увек дешавало. Понеки ученик са оценом 3 достизао је ниво Б2, а неки са оценом 5 - није, што је, вероватно, зависило и од личне мотивације: ученици који су имали 5 - нису давали максимум; ученици који су желели веће оцене - дали су свој максимум. 
Мила Ђуричић

на основном нивоу проблем испитаницима задају питања алтернативног избора, а на напредном питања отвореног типа. Чињеница је да је лексика компликованија на вишим нивоима, те они недовољно добро разумеју питање и не могу да изразе сложену мисао због сопствене пасивне лексике. Резултате представљамо у табели:

\begin{tabular}{|c|c|c|c|c|}
\hline Нивои & $\begin{array}{c}\text { Без } \\
\text { грешке }\end{array}$ & $\begin{array}{c}\text { Са једном } \\
\text { грешком }\end{array}$ & $\begin{array}{c}\text { Са две } \\
\text { грешке }\end{array}$ & $\begin{array}{c}\text { Више од две } \\
\text { грешке }\end{array}$ \\
\hline $\mathbf{A 1}$ & $\begin{array}{c}36 \text { ученика } \\
(81.82 \%)\end{array}$ & $\begin{array}{c}7 \text { ученика } \\
(15.91 \%)\end{array}$ & $\begin{array}{c}1 \text { ученик } \\
(2.27 \%)\end{array}$ & $/$ \\
\hline $\mathbf{A 2}$ & 25 ученика & 13 ученика & 6 ученика & $/$ \\
& $(56.82 \%)$ & $(29.55 \%)$ & $(13.64 \%)$ & \\
\hline $\mathbf{6 1}$ & 21 ученик & 20 ученика & 6 ученика & 2 ученика \\
& $(42.86 \%)$ & $(40.82 \%)$ & $(12.24 \%)$ & $(4.08 \%)$ \\
\hline 62 & 12 ученика & 21 ученик & 13 ученика & 3 ученика \\
& $(24.49 \%)$ & $(42.86 \%)$ & $(26.53 \%)$ & $(6.12 \%)$ \\
\hline
\end{tabular}

\section{Анализа резултата и грешака на нивоима A1 и A2:}

Из табеле видимо да су ученици одлично урадили задатке на A1 нивоу, а да је успешност на нивоу А2 опала за 25\%, као и да се број ученика са грешкама повећао више него двоструко. У нашем истраживању проценат ученика који успешно савлада основни ниво подударио се са $80 \%$, колико је прописано за основни ниво.

На овој етапи ученици су грешили због непажње или брзоплетости. Троје ученика је давало одговоре из којих можемо закључити да нису разумели текст, што је, вероватно, резултат непажљивог или дијагоналног читања. На нивоу А2 ученици, вероватно, нису приступили студиозном читању, због чега је било лако дати погрешан одговор.

На основном нивоу ученицима највећи проблем нису била питања отвореног типа (као што смо очекивали), већ питања алтернативног избора, што може бити везано и за чињеницу 
ПОСТИГНУЋА У РАЗУМЕВАњУ ПИСАНОГ ТЕКСТ НА РУСКОМ ЈЕЗИКУ...

да они нису често решавали овакав тип задатака. Како расте ниво који испитујемо, тако опада број ученика који тачно одговарају на посттекстуалне задатке.У тестовима нивоа Б1 и Б2 ученици по први пут имају више од две грешке.

\section{Анализа резултата и грешака на нивоима Б1 и Б2:}

Ученици су боље одрадили Б1 ниво. Уколико бисмо сматрали да су и ученици који имају једну грешку достигли Б1 ниво - видимо да проценат ученика одговара претпостављеном проценту ученика који треба да задовоље дати стандард. Сматрамо да је ниво Б2 одрађен уз пад концентрације, јер скоро $1 / 4$ испитаника није урадила тест без грешке. Ако упоредимо овај податак са резултатима нивоа Б1, на коме је скоро $43 \%$ одлично урадило тест, не можемо извести закључак да им је текст Мужской и женский русский био тежи, јер је исти проценат ученика имао само једну грешку. Грешке су настајале, јер се није приступало аналитичком читању, појављивали су се половични одговори или их није ни било. Грешке су настајале и услед неудубљивања у текст. На питање отвореног типа ученици најчешће нису ништа одговарали или су одговори били једна реч, често без смисла са задатим питањем, те је нисмо узимали као тачну. Други случај је од ученика захтевао пажљиво ишчитавање текста коме, претпостављамо, ученици нису желели да посвете време, јер су се плашили да не изгубе преостало време за израду. Само један ученик је имао свега један тачан одговор на тесту Б1. Тест Б2 нивоа није урадио. Разлог нам је непознат, као и његова закључна оцена, те не можемо сагледати узрок.

Немамо утисак да су грешке настале услед потпуног неразумевања текста. Напротив, доста грешака је настало услед брзоплетости и неишчитавања текста. Код отворених питања под грешком смо подразумевали непрецизне, ненаписане, бесмислене одговоре или одговоре који су изостали. Њих не сматрамо неуспехом, јер су саставни део наставног процеса, о чему говори и Вјатјутњев: „Грешке представљају средство и услов успешног оваладавања комуникативном компетенцијом. 
Мила Ђуричић

Постојање грешака не сведочи о неуспеху и грешке није неопходно истог тренутка исправљати. Напротив, оне доказују да наставни процес протиче нормално, да учесници активно у њему учествују ${ }^{5 \prime}$ (Вятютнев 1984: 122-124).

Током наставног процеса важно је подстицати ученика на говор и исправљати грешке, често скретати пажњу на њих. Грешка која се једном усвоји на почетној етапи тешко се мења. Док смо читали нетачне одговоре, изненадила нас је чињеница да су их ученици писали, поштујући граматичку и синтаксичку норму. Иу томе се огледа њихово добро познавање језичке структуре.

\section{Закључак}

Разумевање текста и исход су зависили од познавања језика, степена развијености навика и вештина читања на руском као страном, особина и тежине текстова, циља наставе, времена, нивоа предзнања ученика и реализованих часова. Анализа истраживања показује да су ученици најбоље урадили ниво A1 и да на основном нивоу не постоје више од две грешке. Резултати тестова на нивоима Б1 и Б2 показали су да ученици задовољавају нивое предвиђене стандардима постигнућа.

Можемо закључити да ученици који завршавају опште средње образовање у задовољавајућем проценту апсолутно достижу основни, средњи и напредни ниво прописан стандардима постигнућа језичкој вештини читања на руском језику.

После анализе грешака можемо закључити да су ученици Прве београдске гимназије у задовољавајућем проценту достигли сваки од нивоа стандарда постигнућа у језичкој вештини читања, с обзиром на то да се број ученика са једном грешком на напредном нивоу поклопио са бројем ученика који су урадили

5 «Ошибки - это средство и условие успешного овладения коммуникативной компетенцией. Их наличие не свидетельствует о неуспехе и не требует немедленного исправления. Наоборот, они доказывают, что учебный процесс проходит нормально, учащиеся принимают в нем активное участие» (Вятютнев 1984: 122-124). 
задатке без грешке на претходном нивоу. Једну грешку нисмо сматрали релевантном за разумевање читавог текста.

Наша анализа може бити корисна установама које су дефинисале стандарде постигнућа и њихове нивое, јер је показала да су задати параметри оствариви у настави руског језика и процесу наставе језичке вештине читања. Крајњи исход је показао да мотивисани ученици (у нашем истраживању спољашњом мотивацијом - оценом) у „јаким“ српским гимназијама, у којима се руски језик учи само два пута недељно, бивају способни да у даљем развоју и образовању користе руске изворе и читају литературу написану на руском језику, односно да су их наставници на часовима током неколико година оспособили за, условно речено, „беспреводно читање“.

\section{ЛИТЕРАТУРА}

Вјатјутњев 1984: Вятютнев, М. Н. Теория учебника русского языка как иностранного (методические основы). Москва: Русский язык.

Гинић 2016: Гинић, J. Сегментни и супрасегментни фонетски материјал у уџбеницима руског језика за основну школу, Живи језици:часопис за стране језике и књижевности, XXXVI, 1, 187-208.

Завод за вредновање квалитета образовања и васпитања 2015: Општи стандарди постигнућа за крај општег средњег и средњег стручног образовања и васпитања у делу општеобразовних предмета за предмет Страни језик: приручник за наставнике. Београд: Завод за вредновање квалитета образовања и васпитања. [https://ceo. edu.rs/wp-content/uploads/opsti standardi/Strani\%20jezik.pdf, приступљено 20. 6. 2017]

Заједнички европски оквир за живе језике 2003: Ministarstvo prosvjete i nauke Crne Gore: Zajednički evropski okvir za žive jezike: učenje, nastava, ocjenjivanje. Podgorica: Ministarstvo prosvjete i nauke Crne Gore.

Кончаревић 2004: Кончаревић, К. Савремена настава руског језика: садржаји, организација, облици. Београд: Славистичко друштво Србије.

Текстотека ЦМО []

Тешић 1982: Тешић, П. Читање на руском језику и његова улога у процесу комуникације (проблеми читања на генетски блиском језику). Београд: Филолошки факултет. 
Мила Ђуричић

\title{
Мила Джуричич \\ ДОСТИЖЕНИЯ В ПОНИМАНИИ ПРОЧИТАННОГО НА РУССКОМ ЯЗЫКЕ ПОСЛЕ ОБЩЕГО СРЕДНЕГО ОБРАЗОВАНИЯ В СЕРБИИ
}

\begin{abstract}
Резюме
В статье рассматриваются результаты исследования, касающегося обучения чтению в сербских гимназиях с нефилологическим уклоном. Мы уделили особое внимание именно данной речевой деятельности, потому что в обучении русскому как иностранному в Сербии, чтение является одной из наиболее развитых речевых деятельности. Некоторые сербские методисты считают, что обучение чтению достаточно успешное, так как русские и сербские языки относятся к одной группе языков. Благодаря лексике с общим значением в русском и сербском языках, сербы довольно хорошо понимают тексты на русском языке (конечно, если у них есть нужные знания по морфологии и синтаксису, т.е. если они изучают русский язык). В нашем исследовании участвовали ученики Первой белградской гимназии (55 учеников). Мы анализировали их достижения в понимании прочитанного текста на русском языке. Перед ними поставили задачу читать незнакомые адаптированные тексты и отвечать на шесть вопросов. Нас интересовало, достигнут ли ученики компетенции, прописанные сербскими языковыми стандартами. В итоге оказалось, что большинство сербских школьников после среднего образования этой речевой деятельностью владеет на уровне Б2. На практике это значит, что пользователь языком может читать самостоятельно, потому что у него удовлетворительный словарный запас. Чтение литературы, современных и популярных текстов, а также свободное пользование Интернетом ему не предоставят трудности.
\end{abstract}

Ключевые слова: обучение чтению, речевая деятельность, исследование, русский как иностранный, Первая белградская гимназия, беспереводное чтение. 